\title{
Activation of Thromboxane Receptor Mediates Interleukin-8 Expression in Endothelial Cells
}

\author{
Hwa-Jin Jeon ${ }^{1}$, Su-Ryun Kim ${ }^{1,2}$, Hyun-Joo Park ${ }^{1,2}$, Mi-Kyoung Kim ${ }^{1}$, Do-Won Kim ${ }^{1}$, Soo-Kyung Bae ${ }^{2}$, \\ and Moon-Kyoung Bae ${ }^{1 *}$
}

접수: 2013년 1월 2일 / 게재승인: 2013년 1월 29일

(C) 2013 The Korean Society for Biotechnology and Bioengineering

\begin{abstract}
Thromboxane $\mathrm{A}_{2}\left(\mathrm{TXA}_{2}\right)$ is one of major proinflammatory mediators, plays an important role in the development of vascular inflammatory diseases. $\mathrm{TXA}_{2}$ acting through the thromboxane receptor regulates multiple pathways and genes in a variety of cells. In this study, we report that the activation of thromboxane receptor with U46619 increases the interleukin-8 (IL-8) mRNA in vascular endothelial cells. We also demonstrated that $\mathrm{U} 46619$ produces the activations of extracellular signal-regulated kinase 1/2 (ERK1/2) and p38 mitogen-activated protein kinase (MAPK), which is required for endothelial IL-8 production. And U46619 enhanced mRNA stability of IL-8 transcripts in endothelial cells. Moreover, inhibition of ERK1/2 or p38MAPK reduced monocyte adhesion to aortic endothelium stimulated by U46619. Therefore, these results suggest that activation of thromboxane receptor promotes the expression of IL- 8 via ERK1/2 and p38MAPK activation in endothelial cells.
\end{abstract}

Keywords: Thromboxane $\mathrm{A}_{2}$, Thromboxane receptor, Interleukin-8, Vascular endothelial cells

\footnotetext{
${ }^{1}$ 부산대학교 치의학전문대학원 구강생리학교실

${ }^{1}$ Department of Oral Physiology, School of Dentistry, Yangsan Campus of Pusan National University, Yangsan 626-870, South Korea

Tel: +82-51-510-8239, Fax: +82-51-510-8233

e-mail:mkbae@pusan.ac.kr

${ }^{2}$ 부산대학교 치의학전문대학원 치과약리학교실

${ }^{2}$ Department of Dental Pharmacology, School of Dentistry, Yangsan

Campus of Pusan National University, Yangsan 626-870, South Korea
}

\section{1. 서론}

혈관내피세포는 혈관벽을 둘러싸고 혈관의 항상성을 유지 하며, 혈류에서 면역세포들의 혈관외 유출을 조절하는데 중 요한 역할을 하고 있다 [1]. 혈관내피세포는 세포막에 ICAM1, VCAM-1, E-selectin과 같은 세포부착분자들의 발현을 증 가시켜 혈관염증을 유도하는 것으로 알려져 있다 [2]. 또한 염증과정동안 혈관내피세포의 투과도를 증가시켜 백혈구의 이동을 촉진함으로써 혈관외 조직으로의 백혈구 누출을 초래 한다고 한다 [3,4]. 그리고 혈관내피세포는 증식, 이동, 전이, 관형성 과정을 겪으면서 기존의 혈관에서 새로운 혈관을 생 성하는 혈관신생 (angiogenesis)에 관여하고 있다 [5]. 혈관신 생은 배아발생, 상처치유, 암형성과정에서 관찰이 된다. 특 히 병리적 혈관신생은 여러 가지 만성 염증질환의 발병과정 에서 관찰되고 있다 [6]. 이와 같이 혈관염증 및 혈관신생 과 정동안 사이토카인, 케모카인, 성장인자, 세포내 대사산물들 에 의해 매개되어 혈관내피세포의 기능장애 (endothelial dysfucntion)를 초래하는 공통적인 특징을 가진다 [7,8].

Thromboxane $\mathrm{A}_{2}\left(\mathrm{TXA}_{2}\right)$ 는 주된 아라키돈산 대사체로써 사 이클로옥시게나아제 (cyclooxygenase)와 트롬복산 합성효소 (thromboxane synthase)의 일련의 반응에 의해 생합성된 에이 코사노이드 대사체 (eicosanoid metabolite)이다 [9]. $\mathrm{TXA}_{2}$ 는 혈소판 응집, 혈관평활근 수축작용, 획득면역의 조절, 암세 포의 전이와 같은 여러 가지 생리· 병리적 현상을 조절한다. 최근에는 $\mathrm{TXA}_{2}$ 가 혈관내피세포 기능의 생리 · 병리학적인 매개체로 최근 새롭게 주목받고 있다 [10]. $\mathrm{TXA}_{2}$ 는 혈관내 피세포막에 ICAM-1와 VCAM-1과 같은 염증성 막분자들의 
발현증가를 통해 백혈구의 혈관부착능을 증가시킨다 [11]. 또한 $\mathrm{TXA}_{2}$ 는 혈관내피세포의 이동과 혈관신생능, 그리고 혈관투과성을 조절한다고 알려져 있다 [12-14]. 이러한 혈관 내피세포에서의 $\mathrm{TXA}_{2}$ 의 기능은 혈관내피세포막에 존재하 는 트롬복산 수용체 (thromboxane receptor, TP)를 통해 작용 한다. 트롬복산 수용체는 인간에서는 TP $\alpha$ 과 $\mathrm{TP} \beta$, 두 가지 isoform을 가지고 있으며 이들의 활성이 죽상동맥경화증과 같은 혈관성 염증질환에 관여한다 $[15,16]$. 그리고 트롬복산 수용체의 발현 및 트롬복산 수용체의 리간드의 혈장 농도가 여러 가지 심혈관계 질환에서 증가되어 있다고 보고되고 있 다 $[17,18]$.

Interleukin-8 (IL-8)는 호중구의 화학주성인자로 최초 보고 된 이후 백혈구를 비롯한 여러 종류의 세포들에서 분비된다 고 알려져 있다 [18]. 건강한 조직에서는 IL-8의 발현은 거의 발현을 보이지 않지만, tumor necrosis factor 또는 IL-1과 같 은 염증성 사이토카인, 세균성 또는 바이러스성 산물, 세포 외부자극들에 의해 빠르게 발현이 유도된다 [20]. 여러 가지 세포내 신호전달 경로를 통해 IL-8 전사 또는 mRNA 안정성 을 조절하면서 IL-8의 발현을 유도한다고 알려져 있다 [20]. 혈관내피세포에서 IL-8의 기능은 혈관내피세포의 기능이상 을 초래하여 혈관염증, 혈관신생, 혈관투과성을 촉진한다고 한다 [21-23].

본 연구에서는 혈관내피세포에 U46619를 처리하여 트롬 복산 수용체를 활성화 시켰을 때 IL-8의 발현변화 및 그 발현 조절기전에 관하여 연구하였다.

\section{2. 재료 및 방법}

\section{1. 실험재료}

U46619, SB203580, SP600125, U0126, LY294002는 BIOMOL (Plymouth Meeting, PA, USA)에서 구입하여 사용하였다. Phospho-ERK1/2, ERK1/2, phosphor-Akt, Akt, phosph-eNOS, eNOS 항체들은 New England Biolabs (Santa Cruz, CA, USA) 에서 구입하여 사용하였다. Anti- $\alpha$-tubulin 항체는 Biogenex (San Ramon, CA, USA)에서 구입하였다. Actinomycin D는 Sigma (St. Louis, MO, USA)에서 구매하여 사용하였다.

\section{2.세포배양}

실험에 사용한 human microvascular endothelial cells (HMECs)를 미국 $\mathrm{CDC}$ (Atlanta, $\mathrm{GA}$ )에서 획득하여 $37^{\circ} \mathrm{C}$, $95 \%$ 습도, $5 \% \mathrm{CO}_{2}$ 배양기에서 배양하였다. 세포는 $10 \% \mathrm{FBS}$ (Invitrogen, Burlington, Ontario, Canada)에 1\% antibiotics (Hyclon, Logan, Utah, USA)와 $1 \mu \mathrm{g} / \mathrm{mL}$ hydrocortisone (Sigma, St Louis, MO, USA) 및 $10 \mathrm{ng} / \mathrm{mL}$ hEGF (Invitrogen, Gaithersburg, $\mathrm{MD}, \mathrm{USA}$ )를 함유한 성장배지 $\mathrm{MCDB}$ (Invitrogen, Gaithersburg, MD, USA)하에서 배양하면서 실험에 이용하였다. Human umbilical vein endothelial cells (HUVECs) 는 CLONECTICS (Walker Sville, MD, USA)에서 구매하여
5-8 세대 사이의 세포를 실험에 사용하였다. $0.2 \%$ gelatin 이 도말된 세포 배양 접시에 $10 \% \mathrm{FBS}$ 가 함유된 $\mathrm{EGM}-2$ (CLONTECTICS, Walker Sville, MD, USA) 성장 배지를 사 용하여 배양하였다.

\section{3. 역전사-중합효소연쇄반응 (RT-PCR)}

혈관내피세포에서 전체 RNA를 추출하기 위해 TRIzol reagent kit (Invitrogen, Gaithersburg, MD, USA)를 이용하였다. $\mathrm{cDNA}$ 를 합성하기 위하여 $3 \mu \mathrm{g}$ 의 total RNA를 사용하여 역전 사 반응을 시행하였으며, reverse transcription kit (Promega, Madsion, Wl, USA)를 이용하였다. 합성된 cDNA를 $\beta$-actin (sense: 5'-GACTACCTCATGAAGATC-3'antisense: 5'- GAT CCACATCTGCTGGAA-3')과 인간 IL-8 (sense: 5'- GAAGG TGCAGTTTTGCCAAG-3'antisense: 5'-ACCCT CTGCACC CAGTTTTC-3') primer를 이용하여 중합효소연쇄반응 (PCR) 을 시행하였다.

\section{4. 효소결합면역흡착분석법 (Enzyme-linked immunosorbent assays: ELISA)}

혈관내피세포에 U46619를 12시간 동안 처리한 후 배양액을 수집하였다. 이 배양액을 $4^{\circ} \mathrm{C}$ 에서 원심 분리하여 상층액을 얻 었다. 효소결합면역흡착검사키트 (BioLegend, San Diego, CA, USA) 및 포함된 제품 설명서에 의거하여 배양액에 분비된 IL-8 단백질의 농도를 측정하였다.

\subsection{Western immunoblot analysis}

수확한 세포를 2-3회 차가운 PBS로 세척한 후 세포용해 용 액 (40 mM Tris-Cl, $10 \mathrm{mM}$ EDTA, $120 \mathrm{mM} \mathrm{NaCl}, 0.1 \%$ NP40 및 단백질 분해억제 시약)으로 용해시켰다. 각 단백질의 양은 BCA (Sigma, St Louis, MO, USA) 정량법으로 측정하 였다. $30 \mu \mathrm{g}$ 의 전체 단백질을 SDS-PAGE (poly acrylamide gel electrophoresis)로 변성 분리하였고, 이를 nitrocellulose membrane (Amersham Pharmacia Biotech, Piscataway, NJ, USA) 막에 전이시켰다. Membrane의 blocking을 $5 \%$ skim milk가 함유된 PBS-T (PBS, 0.1\% Tween 20) 용액으로 상온 에서 1 시간 동안 실시한 후, 단백질의 발현을 측정하기 위 해 적절한 1 차 항체를 $4^{\circ} \mathrm{C}$ 에서 16 시간 동안 반응시켰다. Horseradish peroxidase가 결합된 이차항체를 실온에서 1시간 반응시키고, 화학발광제 (ECL: Amersham PharmaciaBiotech, Piscataway, NJ, USA)를 반응시킨 후 X-선 필름현상으로 단 백질 발현을 확인하였다.

\subsection{Transient transfection and reporter gene analysis}

일시적인 형질주입 (transient transfection)을 위해서, 혈관내 피세포를 24 well plate에 배양한 후 사람 IL-8 발현조절 영역 부위 (전사 시작부위 -416 에서 +44 부위)를 pGL3- Basic reporter vector (Promega, Madison, WI, USA)에 연결하여 제 작한 luciferase vector를 lipofectamine plus transfection 방법 을 이용하여 도입하였다. 형질주입 48시간 후 분석 키트 
(Promega, Madsion, WI, USA)를 사용하여 세포를 용해시키고, luciferase vector의 활성을 luminometer (Tuner Biosystems, Sunnyvale, CA, USA)를 사용하여 측정하였다.

\section{7. 실시간 중합효소연쇄반응 (Real-time PCR)}

정량적 Real-time PCR은 SYBR Green 방법에 의해 수행하였 다 (Light Cycler; Roche Applied Science, Penzberg, Germany). $\mathrm{PCR}$ 반응 조건은 $95^{\circ} \mathrm{C}$ 에서 10 분간 1주기, 변성 (denaturation) 반응은 $95^{\circ} \mathrm{C}$ 에서 10 초, 결합 (annealing) 반응을 $55^{\circ} \mathrm{C}$ 에 서 5 초, 중합 (extension) 반응을 $72^{\circ} \mathrm{C}$ 에서 7 초간 30 주기를 반 복하여 반응시켰다. 이어 melting curve program이 연속적인 형광 측정을 위해 적용되었다. 또한 Light Cycler software program (version 4.0)을 이용하여 정량적 분석을 실시하였다.

2.8. Ex vivo 단핵구 부착법 (Ex vivo monocyte adhesion assay) 6주령 된 수컷 Sprague-Dawley 쥐는 샘타코 (Seoul, Korea)에 서 구매하여 사용하였다. 쥐에서 분리한 대동맥을 세로로 자 르고 배양배지에 U46619 또는 신호전달경로 저해제를 함께 처리하여 16시간 배양하였다. 그 후 U46619와 배양된 대 동맥은 Calcein-AM (Sigma)으로 형광 염색된 $1 \times 10^{6}$ 개의 단 핵구와 함께 30 분 동안 다시 배양되었다. 배양 후 부착되지 않은 단핵구는 씻어 없애고 부착된 단핵구는 형광 현미경 (Nikon)으로 관찰하여 계수하였다.

\section{9. 통계처리}

본 실험에 대한 실험결과는 세 번 실험하여 얻어진 평균치 및 표준편차를 나타내었고 그룹간의 통계적 차이는 Student's ttest를 이용하여 분석하였다. 대조군과 비교하여 P값이 0.01 미만일 때를 통계적으로 유의성이 있다고 판정하였다.

\section{3. 결과 및 고찰}

\section{1. 트롬복산 수용체 효능제가 혈관내피세포의 IL-8 발현 에 미치는 영향}

트롬복산 수용체 효능제 (agonist)인 U46619가 사람 혈관내 피세포주 $\mathrm{HMEC}$ 의 발현에 어떠한 영향을 미치는지를 관찰 하기 위해 U46619를 농도별로 처리하여 IL-8의 mRNA 발현 을 RT-PCR법으로 조사하였다. 그 결과, Fig. 1(a)에서 보는 바와 같이 $\mathrm{U} 46619$ 를 $1 \mu \mathrm{M}, 10 \mu \mathrm{M}, 30 \mu \mathrm{M}$ 로 2시간 처리하였 을 때, IL-8의 mRNA의 발현이 증가되고 있음을 확인하였다.

\section{2. 세포내 신호전달 인산화효소 저해제가 트롬복산 수용} 체 효능제가 유도하는 IL-8 mRNA 발현에 미치는 영향

트롬복산 수용체 효능제가 여러 가지 세포에서 extracellularsignal-regulated kinase (ERK1/2)와 c-Jun N-terminal kinase (JNK)를 포함하는 mitogen-activated protein kinases (MAPKs) 와 phosphatidylinositol 3-kinase (PI-3K)의 활성을 증가시킨 다 [24,25]. 따라서 여러 가지 특이적 신호전달 인산화효소의
저해제들이 U46619가 유도하는 IL-8의 발현에 어떠한 영향 을 미치는지를 조사하였다. MEK 특이적 저해제인 U0126 또 는 p38MAPK의 선택적 저해제인 SB203580를 HMEC에 전 처리하였을 때 U46619가 유도하는 IL-8의 발현이 $60 \%$ 까지 감소하였다. 그리고 PI-3K 저해제인 LY294002를 전 처리하 였을 때는 U46619가 유도하는 IL-8의 발현에 영향을 끼쳤다. 그러나 JNK 저해제인 SP600125를 처리한 경우에는 효과를 보이지 않았다 (Fig. 1(b)).

(a)

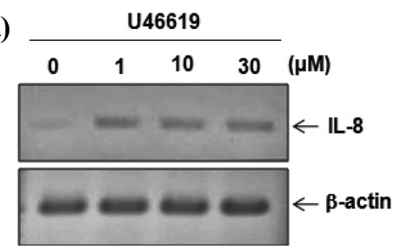

(b)

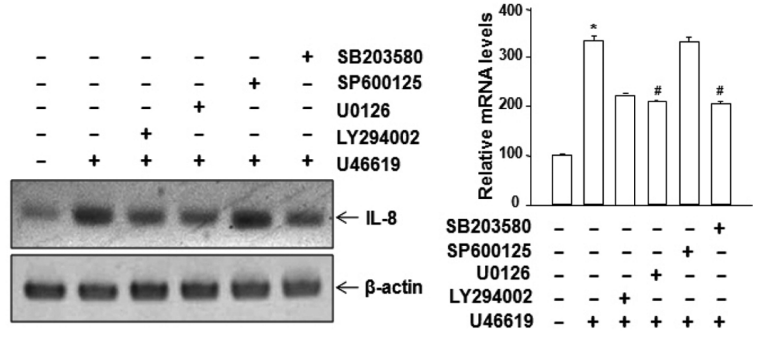

Fig. 1. Effect of U46619 on the expression of IL-8 mRNA. (a) HMECs were treated with U46619 with indicated concentrations for $2 \mathrm{~h}$. Total RNAs were isolated and then analyzed by RT-PCR using specific primers to human IL-8. $\beta$-actin served as an internal control. (b) HMECs were pretreated for $1 \mathrm{~h}$ with or without $2 \mu \mathrm{M}$ of SB203580, SP600125, U0126, or LY294002 prior to stimulation with U46619 $(1 \mu \mathrm{M})$. Total RNAs were isolated and then analyzed by RT-PCR using specific primers to human IL-8. $\beta$-actin served as an internal control. ${ }^{*} P<0.01$ as compared with control; ${ }^{\#} P<0.01$ compared to U46619.

\section{3. 트롬복산 수용체 작용제가 혈관내피세포의 신호전달 인산화효소의 활성에 미치는 영향}

U46619가 혈관내피세포에서 ERK1/2, p38MAPK, Akt의 활 성을 자극하는지를 조사하였다. Fig. 2(a)에서 보는 바와 같 이 U46619는 ERK1/2와 p38MAPK의 인산화를 유도하였으 나, Akt의 인산화는 관찰되지 않았다. 이는 $\mathrm{ERK} 1 / 2$, $\mathrm{p} 38 \mathrm{MAPK}, \mathrm{Akt}$ 의 인산화형을 감지할 수 있는 각각의 특정 항체를 이용한 Western blot 법으로 확인하였다. U46619 처 리는 혈관내피세포의 $\mathrm{ERK} 1 / 2$ 의 인산화를 시간 의존적으로 증가시켰으며 30 분에서 최대효과를 보였다. 그리고 $\mathrm{p} 38 \mathrm{MAPK}$ 의 인산화는 U46619로 혈관내피세포를 자극을 준지 10 분만 에 현격한 증가양상을 보였다 (Fig. 2(b)). 혈관내피세포막에 존재하는 $\mathrm{TXA}_{2}$ 수용체의 isoform의 종류는 $\alpha$ isoform과 $\beta$ isoform이 존재한다고 알려져 있다 [15,16]. 트롬복산 수용체 작용제가 혈관내피세포를 자극하여 IL-8 발현 및 ERK1/2와 p38 신호전달 경로를 활성화 시킬 때 어떠한 종류의 막 수용 체의 isoform이 작용하는 지에 대한 연구는 추가적인 실험을 통해 규명해 낼 필요가 있을 것으로 생각된다. 
(a)

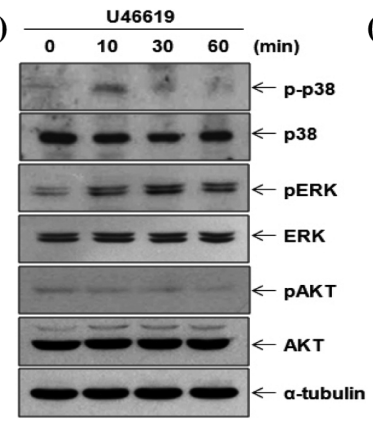

(b)

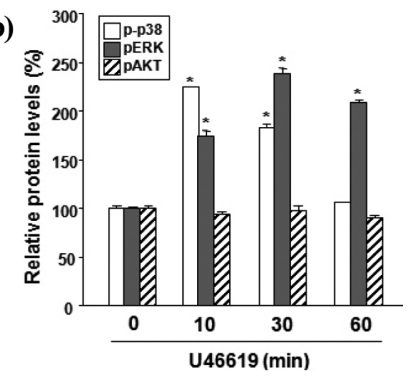

Fig. 2. Effect of U46619 on the activation of ERK $1 / 2$ and p38MAPK. (a) HMECs were treated with U46619 (2 $\mu \mathrm{M})$ for the indicated times. Western blots were probed with anti-phospho-p38, anti-p38, anti- phospho-ERK1/2, anti-ERK1/2, anti-phospho-AKT, and anti-AKT antibodies. $\alpha$-tubulin served as the loading control. (b) The panel showed densitometric analysis assessing relative protein expression levels in at least three times independent experiments. The density of the control bands (untreated) was set to $100 \%$. ${ }^{*} P<0.01$ as compared with control.

\subsection{ERK1/2와 p38MAPK 신호전달이 트롬복산 수용체 효능제가 유도하는 IL-8 단백질 분비에 미치는 영향} 앞서 트롬복산 수용체 작용제가 ERK $1 / 2$ 와 $\mathrm{p} 38 \mathrm{MAPK}$ 의 활 성을 증가시킴을 확인하였다. 따라서 트롬복산 수용체 작용 제가 유도하는 IL-8 단백질 분비에 ERK $1 / 2$ 와 p $38 \mathrm{MAPK}$ 의 저해제가 어떠한 영향을 미치는지 조사하였다. Fig. 3(a)에서 보는 바와 같이 SB203580 또는 U0126가 U46619가 유도하 는 IL-8 단백질분비를 감소시키고 있음을 확인하였다. 예전 보고에서 혈관내피세포에서 트롬복산 수용체 작용제가 IL-8 의 프로모터에 존재하는 NF-B 전사인자의 활성화를 촉진시 킨다고 알려져 있다 [14]. 따라서 U46619가 유도하는 NF-KB 활성에 $\mathrm{ERK} 1 / 2$ 또는 $\mathrm{p} 38 \mathrm{MAPK}$ 이 상위 조절자로써 작용하 는 지 알아보기 위해 NF-kB luciferase 리포터 벡터를 혈관내 (a)

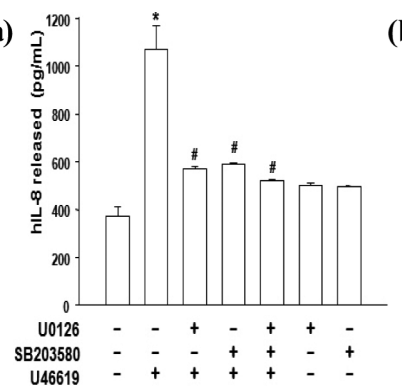

(b)

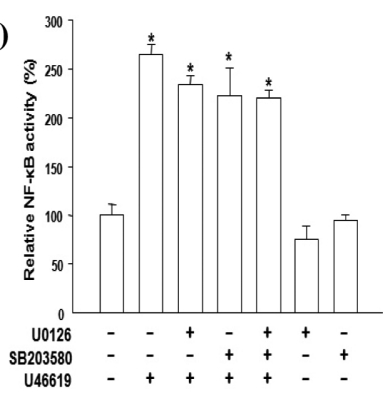

Fig. 3. Effect of ERK1/2 and p38MAPK signaling on U46619induced IL-8 production. (a) HMECs were pretreated with or without SB203580 $(2 \mu \mathrm{M})$ or U0126 $(2 \mu \mathrm{M})$ for $1 \mathrm{~h}$. After stimulation with U46619 $(1 \mu \mathrm{M})$ for $12 \mathrm{~h}$, the production of IL-8 protein was assayed by ELISA. (b) HMECs were transiently transfected with NF-B-dependent luciferase reporter construct and incubated with or without $2 \mu \mathrm{M}$ of SB203580 and U0126 in the presence of U46619 $(1 \mu \mathrm{M})$ for $12 \mathrm{~h}$. Data is the mean $\pm \mathrm{SE}$ of triplicate experiments relative to the luciferase light units in untreated cells (set at $100 \%$ ). ${ }^{*} P<0.01$ as compared with control; ${ }^{\sharp} P<0.01$ compared to U46619.
피세포에 주입하여 관찰하였다. 보고된 바와 같이 U46619를 혈관내피세포에 처리하였을 때는 NF-אB luciferase 활성이 증 가되어 있었다. 하지만 SB203580 또는 U0126 전처리 했을 경우에도 U46619가 유도하는 NF-kB활성에는 영향을 미치 지 않았다 (Fig. 3(b)).

\section{5. 트롬복산 수용체 효능제가 IL-8 mRNA 안정화에 미 치는 영향}

IL-8 유전자는 mRNA 전사수준과 mRNA 안정화의 전사후 수준에서 조절된다고 한다 [20,26]. 따라서 트롬복산 수용체 효능제가 IL-8 mRNA의 안정화에 영향을 주는 지를 전사억 제제인 actinomycin D (ActD)를 이용하여 IL-8 mRNA 감쇠 를 조사하였다. U46619를 $\mathrm{HMEC}$ 에 1시간 동안 처리하고 $\mathrm{ActD}$ 를 첨가한 후 $\mathrm{RNA}$ 를 시간별로 분리하여 $\mathrm{IL}-8$ 의 발현을 조사하였다. Fig. 4(a)에서 보는 바와 같이 ActD가 존재하는 조건에서 $\mathrm{U} 46619$ 가 처리되어 있을 때 $\mathrm{ActD}$ 만 처리되어있을 때 보다 IL-8 mRNA 수준이 천천히 감소되었다. IL-8 mRNA 의 반감기를 real-time RT-PCR 분석법에 의해 정량화하였다. 대조군의 IL-8 mRNA 반감기는 1 시간 미만이었으나, $\mathrm{U} 46619$ 를 처리한 세포에서는 IL-8 mRNA 반감기가 3배이상 늘어났다 (Fig. 4(b)). 따라서 U46619가 IL-8 mRNA 안정화 를 증가시킴을 알 수 있었다. 다음으로는 IL-8 mRNA 안정화 를 조절하는 신호전달 경로를 알아보기 위해 ERK1/2 저해제 (U0126) 또는 p38MAPK의 저해제 (SB203580)를 전처리 하 였다. SB203580은 IL-8 mRNA의 반감기를 약 40분으로 떨 어 뜨렸고, U0126를 처리한 군에서는 IL-8 mRNA 반감기를 1 시간으로 낮췄다. 이들 결과는 p38MAPK 또는 ERK1/2 경

(a)
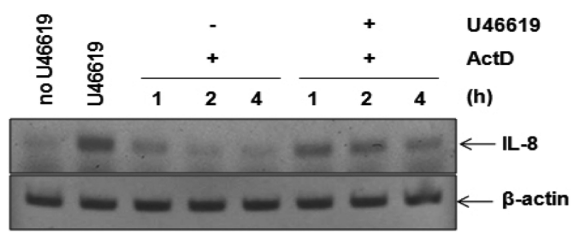

(b)

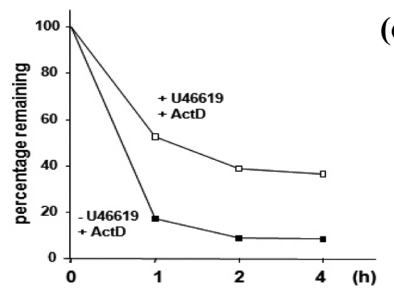

(c)

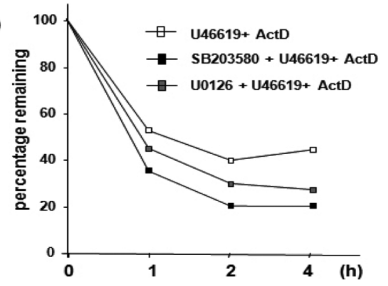

Fig. 4. Stabilization of IL-8 mRNA by U46619 in endothelial cells. HMECs were pretreated with U46619 $(1 \mu \mathrm{M})$ for $1 \mathrm{~h}$ and then stimulated with or without $\mathrm{U} 46619(1 \mu \mathrm{M})$ maintained in fresh medium containing $5 \mu \mathrm{g} / \mathrm{mL}$ ActD. (a) Total RNAs were isolated and then analyzed by RT-PCR using specific primers to human IL8. $\beta$-actin served as an internal control. (b) Using real-time RTPCR, we also quantified the expression levels of human IL-8 mRNA. The expression level of control (untreated) was set to 100 , and the values are normalized to $\beta$-actin mRNA levels. (c) Cells were treated with U46619 in either in the presence or absence of SB203580 or U0126, and the IL-8 mRNA stability were determined after addition of ActD. 
로를 통해 IL-8 mRNA 안정화를 조절하는 것으로 여겨진다. 이와 같이 트롬복산 수용체 효능제는 혈관내피세포에서 NF-B 활성을 통해 IL-8 mRNA 전사조절을 하며 [14], ERK1/ 2 와 $\mathrm{p} 38 \mathrm{MAPK}$ 경로를 통해 IL-8 mRNA 전사후 조절이 이루 어짐을 알 수 있다. 특히 $\mathrm{p} 38 \mathrm{MAPK}$ 경로를 통해 MAPKactivated protein kinase-2 (MK2)을 활성화시킴으로써 IL-8의 전사 후 수준에서의 조절됨이 잘 알려져 있다 [27]. 향후 혈 관내피세포에서 트롬복산 수용체 효능제의 활성화에 따른 $\mathrm{MK} 2$ 의 활성 조절여부는 추가적인 연구가 필요할 것이다.

\section{6. 트롬복산 수용체 효능제가 유도한 혈관염증과정에서 ERK1/2 및 p38MAPK 신호전달 경로의 관련성}

혈관염증 과정동안 단핵구는 활성화된 혈관내피세포에 모 여들고 굴러가서 빠져나가게 된다. 이 과정에 혈관내피세포 는 IL-8 등에 의해 비정상적인 활성화 과정을 겪게 된다 [28]. 이와 같이 IL-8는 단핵구가 혈관내피세포에 부착되는 혈관 염증의 강력한 매개체로 잘 알려져 있다 [29]. 또한 외부자극 에 의해 증가된 $\mathrm{TXA}_{2}$ 를 통해 ex vivo 대동맥에서 IL-8 발현 이 증가되어 있음이 보고되어 있다 [30]. 따라서 트롬복산 수 용체 효능제가 유도한 혈관염증과정에 ERK $1 / 2$ 및 $\mathrm{p} 38 \mathrm{MAPK}$ 신호전달 경로가 관여하고 있는지 조사하기 위해 ERK1/2와 $\mathrm{p} 38 \mathrm{MAPK}$ 의 저해제를 쥐에서 분리해낸 대동맥에 처리하여 단핵구와 대동맥의 부착정도를 관찰하였다. Fig. 5 에서 보는 바와 같이 SB203580 또는 U0126가 전처리된 대동맥에서는 U46619가 유도하는 단핵구와 대동맥의 부착능을 저해시키

(a)
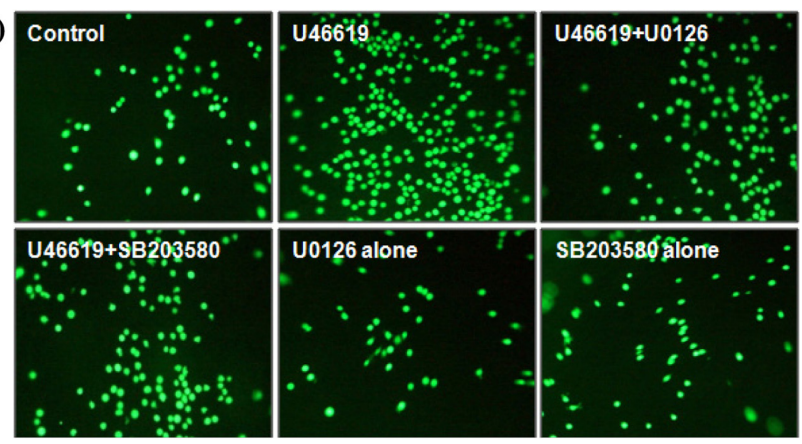

(b)

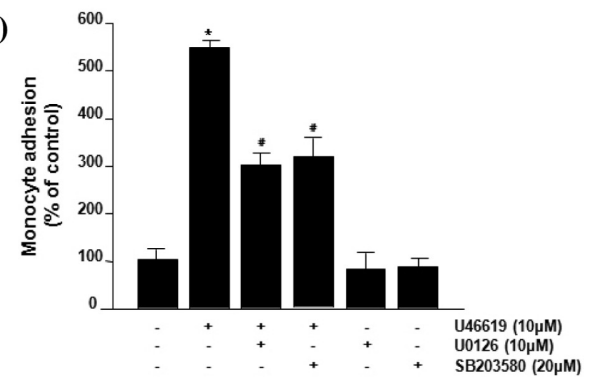

Fig. 5. Effect of U46619 on adhesion of monocytes to aortic endothelium ex vivo. (a) Rat aorta was isolated, incubated with or without U46619 for 16 h, and photographed. (b) Fluorescencestained monocytes were identified and counted by fluorescence microscopy at $40 \mathrm{X}$ magnification. Data is the mean $\pm \mathrm{SE}$ relative to adhesion of untreated cells (set at $100 \%$ ) in triplicate experiments. ${ }^{*} P<0.01$ as compared with control; ${ }^{*} P<0.05$ compared to U46619.
고 있음을 확인하였다. 향후 U46619가 유도하는 혈관염증에 관한 추가적인 실험을 통하여 IL-8 분비에 의한 ICAM-1, VCAM-1 같은 세포부착인자와의 상관관계를 규명해 낼 필 요가 있을 것으로 생각된다.

\section{4. 졀론}

트롬복산 수용체 작용제가 혈관내피세포의 IL-8의 발현 및 발현조절 기전을 관찰한 결과 다음과 같은 결론을 얻었다.

(1) 트롬복산 수용체 작용제 U46619는 혈관내피세포에서 IL-8 mRNA 발현을 증가시킨다.

(2) U46619가 혈관내피세포에서 ERK1/2 및 p38MAPK8 의 활성을 촉진시킨다.

(3) U46619가 유도하는 IL-8 단백질 분비를 ERK1/2와 p38MAPK 신호전달 경로가 매개한다.

(4) U46619가 IL-8 mRNA 안정화를 증가시키며, 이를 $\mathrm{ERK} 1 / 2$ 와 p38MAPK 신호전달 경로가 관여한다.

(5) U46619가 유도하는 염증세포와 혈관내피세포 사이의 부착능을 $\mathrm{ERK} 1 / 2$ 와 $\mathrm{p} 38 \mathrm{MAPK}$ 저해제가 감소시킨다. 이상의 결과로 트롬복산 수용체 작용제가 $\mathrm{ERK} 1 / 2$ 와 p38MAPK 신호전달 경로를 통해 IL-8 mRNA 발현 및 분비 를 유도하고, 이를 통해 혈관염증을 조절하고 있음을 알 수 있다. 따라서 트롬복산 수용체 조절 약물 및 $\mathrm{TXA}_{2}$ 분비 제어 약물의 개발은 향후 혈관염증 치료제로 활용될 가능성이 높 을 것으로 생각된다.

\section{감사}

이 논문은 부산대학교 자유과제 학술연구비 (2년)에 의하여 연구되었음.

\section{REFERENCES}

1. Stevens, T., J. G. Garcia, D. M. Shasby, J. Bhattacharya, and A. B. Malik (2000) Mechanisms regulating endothelial cell barrier function. Am. J. Physiol. Lung Cell. Mol. Physiol. 3: L419-422.

2. Ley, K., C. Laudanna, M. I. Cybulsky, and S. Nourshargh (2007) Getting to the site of inflammation: the leukocyte adhesion cascade updated. Nat. Rev. Immunol. 9: 678-689.

3. Muller, W. A. (2003) Leukocyte-endothelial-cell interactions in leukocyte transmigration and the inflammatory response. Trends Immunol. 6: 327-334.

4. Bates, D. O. and S. J. Harper (2002) Regulation of vascular permeability by vascular endothelial growth factors. Vascul Pharmacol. 4-5: 225-237.

5. Carmeliet, P. (2003) Angiogenesis in health and disease. Nat. Med. 6: $653-660$.

6. Carmeliet, P. and R. K. Jain (2000) Angiogenesis in cancer and 
other diseases. Nature 6801: 249-257.

7. Otrock, Z. K., R. A. Mahfouz, J. A. Makarem, and A. I. Shamseddine (2007) Understanding the biology of angiogenesis: review of the most important molecular mechanisms. Blood Cells Mol. Dis. 2: $212-220$.

8. Liu, W., S. A. Ahmad, N. Reinmuth, R. M. Shaheen, Y. D. Jung, F. Fan, and L. M. Ellis (2000) Endothelial cell survival and apoptosis in the tumor vasculature. Apoptosis 4: 323-328.

9. Iniguez, M. A., C. Cacheiro-Llaguno, N. Cuesta, M. D. DiazMunoz, and M. Fresno (2008) Prostanoid function and cardiovascular disease. Arch. Physiol. Biochem. 3: 201-209.

10. Alfranca, A., M. A. Iniguez, M. Fresno, and J. M. Redondo (2006) Prostanoid signal transduction and gene expression in the endothelium: role in cardiovascular diseases. Cardiovasc. Res. 3: 446-456.

11. Ishizuka, T., M. Kawakami, T. Hidaka, Y. Matsuki, M., Takamizawa, K. Suzuki, A. Kurita, and Nakamura, H. (1998). Stimulation with thromboxane A2 (TXA2) receptor agonist enhances ICAM-1, VCAM-1 or ELAM-1 expression by human vascular endothelial cells. Clin. Exp. Immunol. 3: 464-470.

12. Nie, D., M. Lamberti, A. Zacharek, L. Li, K. Szekeres, K. Tang, Y. Chen, and K. V. Honn (2000) Thromboxane A(2) regulation of endothelial cell migration, angiogenesis, and tumor metastasis. Biochem. Biophys. Res. Commun. 1: 245-251.

13. Daniel, T. O., H. Liu, J. D. Morrow, B. C. Crews, and L. J. Marnett (1999) Thromboxane A2 is a mediator of cyclooxygenase- 2dependent endothelial migration and angiogenesis. Cancer Res. 18: 4574-4577.

14. Kim, S. R., S. K. Bae, H. J. Park, M. K. Kim, K. Kim, S. Y. Park, H. O. Jang, I. Yun, Y. J. Kim, M. A. Yoo, and M. K. Bae (2010) Thromboxane A(2) increases endothelial permeability through upregulation of interleukin-8. Biochem. Biophys. Res. Commun. 3: 413-419.

15. Ashton, A. W., Y. Cheng, A. Helisch, and J. A. Ware (2004) Thromboxane A2 receptor agonists antagonize the proangiogenic effects of fibroblast growth factor-2: role of receptor internalization, thrombospondin-1, and alpha(v)beta3. Circ. Res. 6: 735-742.

16. Michel, F., J. S. Silvestre, L. Waeckel, S. Corda, T. Verbeuren, J. P. Vilaine, M. Clergue, M. Duriez, and B. I. Levy (2006). Thromboxane $\mathrm{A} 2$ /prostaglandin $\mathrm{H} 2$ receptor activation mediates angiotensin II-induced postischemic neovascularization. Arterioscler. Thromb. Vasc. Biol. 3: 488-493.

17. Nakahata, N. (2008) Thromboxane A2: physiology/pathophysiology, cellular signal transduction and pharmacology. Pharmacol. Ther. 1: 18-35.

18. Dogne, J. M., J. Hanson, and D. Pratico (2005) Thromboxane, prostacyclin and isoprostanes: therapeutic targets in atherogenesis. Trends Pharmacol. Sci. 12: 639-644.

19. Baggiolini, M., B. Dewald, and B. Moser (1994) Interleukin-8 and related chemotactic cytokines-CXC and $\mathrm{CC}$ chemokines. $A d v$.
Immunol. 97-179.

20. Hoffmann, E., O. Dittrich-Breiholz, H. Holtmann, and M. Kracht (2002). Multiple control of interleukin-8 gene expression. J. Leukoc. Biol. 5: 847-855.

21. Li, A., S. Dubey, M. L. Varney, B. J. Dave, and R. K. Singh (2003) IL-8 directly enhanced endothelial cell survival, proliferation, and matrix metalloproteinases production and regulated angiogenesis. J. Immunol. 6: 3369-3376.

22. Biffl, W. L., E. E. Moore, F. A. Moore, V. S. Carl, R. J. Franciose, and A. Banerjee (1995) Interleukin-8 increases endothelial permeability independent of neutrophils. J. Trauma 1: 98-102; discussion 102-3.

23. Reutershan, J., M. A. Morris, T. L. Burcin, D. F. Smith, D. Chang, M. S. Saprito, and K. Ley (2006) Critical role of endothelial CXCR2 in LPS-induced neutrophil migration into the lung. $J$. Clin. Invest. 3: 695-702.

24. Bayat, H., S. Xu, D. Pimentel, R. A. Cohen, and B. Jiang (2008) Activation of thromboxane receptor upregulates interleukin (IL)1beta-induced VCAM-1 expression through JNK signaling. Arterioscler. Thromb. Vasc. Biol. 1: 127-134.

25. Miggin, S. M. and B. T. Kinsella (2001) Thromboxane A(2) receptor mediated activation of the mitogen activated protein kinase cascades in human uterine smooth muscle cells. Biochim. Biophys. Acta 1-2: 147-162.

26. Subramaniam, D., S. Ramalingam, R. May, B. K. Dieckgraefe, D. E. Berg, C. Pothoulakis, C. W.Houchen, T. C.Wang, and S. Anant (2008) Gastrin-mediated interleukin-8 and cyclooxygenase-2 gene expression: differential transcriptional and posttranscriptional mechanisms. Gastroenterology 4: 1070-1082.

27. Winzen, R., M. Kracht, B. Ritter, A. Wilhelm, C. Y.Chen, A. B. Shyu, M. Muller, M. Gaestel, K. Resch, and H. Holtmann (1999) The p38 MAP kinase pathway signals for cytokine-induced mRNA stabilization via MAP kinase-activated protein kinase 2 and an AU-rich region-targeted mechanism. EMBO J. 18: 49694980.

28. Babu, P. V., H. Si, Z. Fu, W. Zhen, and D. Liu (2012) Genistein prevents hyperglycemia-induced monocyte adhesion to human aortic endothelial cells through preservation of the cAMP signaling pathway and ameliorates vascular inflammation in obese diabetic mice. J. Nutr. 4: 724-730.

29. Srinivasan, S., M. Yeh, E. C. Danziger, M. E. Hatley, A. E. Riggan, N. Leitinger, J. A.Berliner, and C. C. Hedrick (2003) Glucose regulates monocyte adhesion through endothelial production of interleukin-8. Circ. Res. 4: 371-377.

30. Kim, S. R., Y. H. Jung, H. J. Park, M. K. Kim, J. W. Jeong, H. O. Jang, I. Yun, S. K. Bae, and M. K. Bae (2012) Upregulation of thromboxane synthase mediates visfatin-induced interleukin-8 expression and angiogenic activity in endothelial cells. Biochem. Biophys. Res. Commun. 4: 662-668. 